Studia Judaica 22 (2019), nr 1 (43), s. 9-30

doi:10.4467/24500100STJ.19.002.11229

Eugenia Prokop-Janiec

\title{
Polish Language in Jewish Daily Life: The Press and Popular Literature in the 1930s
}

\begin{abstract}
This article discusses the spread of the Polish language among the Jewish population in the 1930s. Its source is the daily press, which was one of the most important institutions of interwar Jewish culture in the Polish language and one of the key institutions in which Polish served as a means of written communication in Jewish life.

The press can be regarded as one of the principle sources indicating the main modern areas of Jewish communication in Polish and documenting the expansion of this communication from the public to the private sphere, from the exchange of opinions on social, political, and artistic problems to the discussion of everyday issues, family life, or even the most intimate subjects. The Polish-Jewish popular daily press created opportunities for speaking about everyday life through journalistic and literary genres dealing with topics related to family, marriage, sex, health, fashion, cooking, housekeeping, raising children, schools and universities, sport, entertainment, etiquette. The appearance of Polish-Jewish sensationalist newspapers at the beginning of the 1930s signaled the emergence of new audiences using the Polish language. The interwar vernacularization of the Polish language manifests itself in its growing instrumental value and change in its symbolic signification. The increasingly widespread use of Polish was accompanied by the weakening of its role as a symbol of integration with Polishness and Polish culture.
\end{abstract}

Keywords: Jews in Poland in the twentieth century, Jewish press in the Polish language, sensationalist Jewish dailies in the Polish language, popular Polish-Jewish literature.

Słowa kluczowe: Żydzi w Polsce w XX wieku, prasa żydowska w języku polskim, sensacyjne dzienniki żydowskie w języku polskim, popularna literatura polsko-żydowska. 


\section{Linguistic Polonization}

In Jewish life in Poland, the period from 1918 to 1939 was an era of progressive linguistic Polonization. Both the observers of social life at the time and present-day researchers agree that this process intensified in successive interwar decades. It is difficult, however, to substantiate this opinion with reliable statistical data which could serve to identify the precise scope of the phenomenon. The two general censuses taken at the beginning of the 1920s and 1930s unfortunately failed to provide them. This was related to the usual difficulties of obtaining reliable ethnic data through such censuses $^{1}$ (reflected also in socio-linguistic issues ${ }^{2}$ ), as well as to the unusual historical and political circumstances in which these operations took place.

Conducted in the country whose boundaries had still not been fully established, the census of 1921 omitted several regions (Upper Silesia and the Vilna Region). Hence the data collected were incomplete, and the linguistic statistics obtained at the time were never announced. The questions asked both about language and nationality. ${ }^{3}$ The pamphlet Co nam da spis ludności [What Do We Gain from the Census?] justifies the census form, arguing that "the inclusion of these two mutually complementary questions offers the advantage of greater precision and makes it possible to provide an exact and objective picture of complicated relations." ${ }^{4}$ The respondents were not given a list of languages to choose from ${ }^{5}$ and could declare the use of two mother tongues. ${ }^{6}$ In evaluating the reliability of the

${ }^{1}$ For more information on the difficulties of obtaining ethnic data and their reliability, see Lucjan Adamczuk, Sławomir Łodziński, "Wprowadzenie," in eid. (eds.), Mniejszości narodowe w Polsce w świetle Narodowego Spisu Powszechnego z 2002 roku (Warsaw, 2006), 14.

${ }^{2}$ Mirosława Sagan-Bielawa, "Pytanie o język w spisach ludności na ziemiach polskich (lata 1789-2011)," in Władysław T. Miodunka, Anna Seretny (eds.), Język, literatura i kultura polska w świecie (Kraków, 2016), 179-192.

${ }^{3}$ Marcin Nadobnik, "Pierwszy spis ludności w Polsce: Najważniejsze wiadomości o przyszłym spisie z dnia 30 września 1921 roku," in Zbigniew Strzelecki, Tadeusz Toczyński, Kazimierz Latuch (eds.), Spisy ludności w Rzeczypospolitej Polskiej 1921-2002: Wybór pism demografów (Warsaw, 2002), 128; Henryk Grossman, "Znaczenie i zadania pierwszego powszechnego spisu ludności w Polsce,” in Strzelecki, Toczyński, Latuch (eds.), Spisy ludności, 108.

${ }^{4}$ Co nam da spis ludności (Warsaw, 1921), 2.

5 Henryk Grossman emphasized that this method did not impose any classification. See Grossman, "Znaczenie i zadania pierwszego powszechnego spisu ludności," 108.

${ }^{6}$ In 1930, this approach was described as incorrect by the General Census Commissioner Rajmund Buławski, see Rajmund Buławski, "Metody statystyczne badania stosunków narodowościowych w spisach ludności," in Strzelecki, Toczyński, Latuch (eds.), Spisy ludności, 198. 
results, Ludwik Krzywicki pointed out that the census had taken place during Jewish holidays, so there had been some cases of Jews refusing to participate. He also gave examples of hesitations among the Jewish respondents and changes in their declared mother tongue. ${ }^{7}$

The census of 1931, on the other hand, took place in an atmosphere of mobilization among national minorities. This may be explained by the fact that the question about nationality was dropped from the revised census form. Rajmund Buławski justified this change by the census authorities, claiming that "in our circumstances, as in most countries, the native tongue is the best indication of nationality." "Moreover, it was no longer possible to declare bilingualism, since it was argued that "one can no more speak two native tongues at the same time than one can belong to two different nationalities at the same time." Nor did the census ask about the use of other languages apart from the first language. ${ }^{10}$

The replacement of the question about nationality with the question about native tongue was criticized by minorities. In a query addressed to the Minister of Internal Affairs by the Jewish parliamentary group on 20 October 1931, they recalled the practice of the 1921 census and the way it was justified at the time. They emphasized that " $[\mathrm{t}]$ he native tongue [was] not ... the only criterion for determining nationality" and pointed out that, "[g]iven the linguistic conditions prevailing among the Jews, answering the language question [would] not fill the gap [in the census form]." ${ }^{11}$ Ultimately, however, the answer to the question about the mother tongue became a substitute declaration of national identity. In fact, the Polish-language Jewish press called on its readers to declare Hebrew as their native language, irrespective of whether they actually knew it or used it for everyday communication. This was essentially consistent with the position of the census authorities, which defined the native tongue as "the one regarded by the respondent as the closest to him," "the one

7 See Ludwik Krzywicki, "Wartość wyników spisu jednodniowego," in Strzelecki, Toczyński, Latuch (eds.), Spisy ludności, 132, 141-142.

${ }^{8}$ Buławski, "Metody statystyczne," 191.

${ }^{9}$ Ibid., 199.

${ }^{10}$ Buławski justified this with the peculiar linguistic situation in Poland after the period of partitions. See ibid., 202.

11 "Interpelacja koła żydowskiego i odpowiedź ministra spraw wewnętrznych w sprawie rubryki 'narodowość' na formularzu spisowym ludności oraz naruszania praw języka żydowskiego w instrukcji spisowej," in Strzelecki, Toczyński, Latuch (eds.), Spisy ludności, 225, 226. They also noted that the minority languages approved for use in the census documents did not include Yiddish. 
in which he thinks and which he uses among family members." ${ }^{12}$ Such an interpretation was further confirmed and validated by the Minister of Internal Affairs, Bronisław Pieracki, who, in his answer to the query, stated:

The term "native tongue" is framed by the present census in such a manner that the respondents are completely free to choose a language in which they are less fluent and which they use less frequently. The choice of the language that should be regarded as native is left to the respondents and is meant to identify the language that is emotionally closest to them..$^{13}$

According to the census of 1931, out of the 3,114 thousand citizens of Jewish religion, 2,489 thousand (about 80 per cent) declared their mother tongue as Yiddish, and 243,539 (about 8 per cent) stated that their first language was Hebrew. The remaining 12 per cent of the Jews claimed their mother tongue was Polish. ${ }^{14}$

In his study on the trilingual culture of the Jews in interwar Poland, Chone Shmeruk interprets these data as untrustworthy and inaccurate, not only with regard to the speakers of Hebrew, but also of Yiddish. Untrustworthy-because some of those who declared Hebrew or Yiddish as their first languages did so only for ideological reasons, and inaccurate-because most of the respondents knew and spoke more than one language, which the census questions failed to accommodate. ${ }^{15}$

The East-European Jews were a multilingual ${ }^{16}$ and linguistically multicompetent community, using many languages with varying degrees of fluency. ${ }^{17}$ The character of their multilingualism and multicompetence evolved under the influence of local historical and political factors. In

12 Buławski, "Metody statystyczne," 197.

13 "Odpowiedź Ministra Spraw Wewnętrznych," in Strzelecki, Toczyński, Latuch (eds.), Spisy ludności, 227. See also Rajmund Buławski, "Kwestia narodowościowa w programie Drugiego Powszechnego Spisu Ludności Rzeczypospolitej Polskiej," in Strzelecki, Toczyński, Latuch (eds.), Spisy ludności, 208.

14 "Drugi Powszechny Spis Ludności z dnia 9 grudnia 1931 r. Ludność obecna według języka ojczystego na podstawie spisu z dn. 9 XII 1931 r.: Wyniki tymczasowe," Wiadomości Statystyczne (1932), 16.

${ }^{15}$ Chone Shmeruk, "Hebrew-Yiddish-Polish: A Trilingual Jewish Culture," in Yisrael Gutman, Ezra Mendelsohn, Jehuda Reinharz, Chone Shmeruk (eds.), The Jews of Poland between Two World Wars (Hanover-London, 1989), 288.

${ }^{16}$ Benjamin Harshav, "Polilingualism," in id., The Polyphony of Jewish Culture (Stanford, 2007), 23-40.

${ }^{17}$ For more details on the meaning of linguistic multicompetence, see Monika Bednarczuk, "Wielojęzyczność w kontekście akademickim: Sieci naukowe, samodoskonalenie i polityka w Wilnie (w końcu XVIII i pierwszych dekadach XIX wieku), Wielogłos 2 (2016), $30-31$. 
the interwar period, the dominant pattern became the so-called external bilingualism, that is, Yiddish-Polish bilingualism, and Polish began to acquire the status of the vernacular language. ${ }^{18}$ Alter Drujanow, a Zionist and Hebrew writer, after his visit to Poland in 1932 (i.e. one year after the census) warned:

The linguistic assimilation of the Jews in Poland has intensified to such a degree that before our very eyes they seem to be forgetting the language that has been their own for hundreds of years... Who knows whether communication in Yiddish will still be possible among the Jews in the next generation or two. ${ }^{19}$

Foremost among the factors that favored linguistic Polonization was certainly the expansion of school education: the reborn Polish state, its educational system, and cultural policies formed a new institutional framework for this process. This framework provided a space for what was described in the 1930s as "the mutual interpenetration of Jewish culture and the Polish language." ${ }^{20}$ The growing scale and endurance of this phenomenon gave rise to increasingly common calls for "developing ... Jewish nationality within the framework of the Polish language." 21 This situation was viewed with concern by those Jewish circles which regarded the process of linguistic Polonization as tantamount to national assimilation and therefore insisted on "the Judaization of state primary schools established exclusively for Jewish children" 22 and on reducing the number of school subjects taught in Polish. ${ }^{23}$ In the late 1930s, Yiddishists explicitly called for creating a league of "the Yiddish speakers," which would act as an anti-Polonizing force..$^{24}$

An assessment of the extent of linguistic Polonization, made from a peculiar vantage point, can be found in The Chronicle of the Warsaw Ghetto (in entries from May 1942) written in Yiddish by Emanuel Ringelblum:

${ }^{18}$ Celia Stopnicka Heller, On the Edge of Destruction: Jews of Poland between the Two World Wars (New York, 1980).

${ }^{19}$ Nathan Cohen, "Zapominanie języka: Polszczyzna i jidysz wśród młodzieży żydowskiej w międzywojennej Polsce," trans. Izabela Suchojad, in Eugenia Prokop-Janiec, Marek Tuszewicki (eds.), Polskie tematy i konteksty literatury żydowskiej (Kraków, 2014), 270.

${ }^{20}$ Chaim Löw, Smok w stowiczym gnieździe: Żydzi w poezji Odrodzonej Polski (Warsaw, 1934), 9.

${ }^{21}$ Samuel Hirszhorn, "Czy istotnie asymilacja triumfuje," Nasz Przegląd 8 (1930), 4.

22 "Przeciwko asymilacji," Nasz Przeglad 3 (1925), 58.

${ }_{23}$ Moshe Kleinbaum, "Czy przymusowa utrakwizacja szkolnictwa hebrajskiego," Opinia 1 (1933), 37.

${ }^{24}$ Cohen, "Zapominanie języka," 271. 
People readily speak in Polish. The Jewish language is very seldom heard in the streets . . . [I]t is evidence of a very strong assimilation process, which occurred already before the war and now has become even more evident in the Jewish environment. As long as the streets were filled with mixed population, it was not so noticeable, but now that there are only Jews in the streets, one can see how far this process has gone. ${ }^{25}$

In the same year, in an interview conducted for the Oneg Shabbat underground archive, writer Hillel Zeitlin formulated it critically and emotionally: "The Jews ... speak Polish with delight. The Polish language became a holy ghetto tongue, the holy tongue of the Jews in the ghetto." 26

\section{New perspectives and sources for research}

In recent years, some new research methods have been suggested for assessing the spread of the Polish language and the pace of linguistic Polonization in the interwar period. A very interesting model has been proposed by Nathan Cohen, who in his studies uses data provided by interwar library statistics. Cohen begins by distinguishing two forms of linguistic Polonization: the oral one and the one related to literacy. This process included, first, the transition from spoken Yiddish to Polish and, second, the transition from reading in the Jewish languages to reading in Polish. It is the latter form of Polonization that can be studied through data collected by library institutions. Modern, non-religious Jewish libraries were multilingual. ${ }^{27}$ Cohen has interpreted data regarding their book collections, available in surviving catalogues and library documents, including purchase records and statistics on the readers' borrowings. Even the very size of the book collection in a given language is-in his opinion-indicative of the position of this language, as it reveals how well and how widely it was known among the readers. Further information is provided by changes in the book purchasing policy: an expansion of the book collection in a given language signals a growing demand and interest among the library's patrons. Other important information comes from the borrowing statistics which show the circulation of books in different languages. Cohen's

${ }^{25}$ Emanuel Ringelblum, Kronika getta warszawskiego: Wrzesień 1939 - styczeń 1943, trans. Adam Rutkowski (Warsaw, 1988), 388.

${ }^{26}$ Justyna Majewska, “'Czym wytłumaczy Pan...?’ Inteligencja żydowska o polonizacji i asymilacji w getcie warszawskim," Zagłada Żydów 11 (2015), 343.

${ }^{27}$ On public Jewish libraries as one of the means of contact with modern ideas see Jeffrey Veidlinger, Jewish Public Culture in the Late Russian Empire (Bloomington, 2009). 
analyzes of interwar documents of libraries in Warsaw, Białystok, and Vilna demonstrate a growing importance of the Polish language. In the 1930s, Polish book collections and borrowings increased even in libraries run by Yiddishist institutions. ${ }^{28}$

In my article, I would like to propose a complement to Cohen's description. However, I am not interested here in the numerical indicators of Polonization, confirming the presence and expansion of the Polish language in Jewish life, but rather in offering some evidence of what might be described as the vernacularization of Polish. The Latin adjective vernaculus means 'domestic,' 'one's own,' 'native,' 'local.' The vernacular language is a language of everyday communication among a group of peopletheir colloquial, home speech. This function distinguishes a vernacular language from an official language or a lingua franca. As demonstrated by Jeffrey Shandler's research, in describing the mutating matrix of the Jewish languages, it is possible to take into account their vernacular status. ${ }^{29}$ In analyzing the role of Polish, it may also be useful to distinguish, as Shandler does, between the primary instrumental value of signification of a language and its secondary symbolic signification. According to this approach, the interwar vernacularization of the Polish language manifests itself in its growing instrumental value and changes in its symbolic signification. For it is evident that the increasingly widespread use of Polish was accompanied by the weakening of its role as a symbol of integration with Polishness and Polish culture, the role it was given by nineteenth-century assimilationist programs. ${ }^{30}$

My source will be the daily press, which was one of the most important institutions of interwar Jewish culture in the Polish language. Students of modern culture call the newspaper a "one-day best-seller" and regard it as a form of book or an "extreme form" of the book. ${ }^{31}$ Sociologists treat the readership of books and newspapers as a single category, but they also note differences between them, pointing out that the readership of

${ }^{28}$ Nathan Cohen, "Czytelnictwo książek polskich w żydowskich bibliotekach w okresie międzywojennym," trans. Eugenia Prokop-Janiec, in Eugenia Prokop-Janiec, Sławomir J. Żurek (eds.), Literatura polsko-żydowska: Studia i szkice (Kraków, 2011), 21-26.

${ }^{29}$ Jeffrey Shandler, Adventures in Yiddishland: Postvernacular Language and Culture (Berkeley, 2006), 4-5.

${ }^{30}$ For more on the symbolic role of Polish in integrationist programs, see Agnieszka Jagodzińska, Pomiędzy: Akulturacja Żydów Warszawy w drugiej połowie XIX wieku (Wroclaw, 2008), 140-142.

${ }^{31}$ Benedict Anderson, Imagined Communities: Reflections on the Origin and Spread of Nationalism (New York, 2006), 34-35. 
the press is often a more widespread form of participation in culture, especially among people with lower education and cultural competence. ${ }^{32}$

Like Cohen, I will therefore focus on the practices of reading in Polish that were prevalent among Jews in the interwar period, but I will analyze them in one particular aspect. I am interested not so much in their prevalence, as rather in the nature of content that was made available to the Jewish reader. Therefore, I am not going to analyze press circulation, sales figures, or estimates of readership, but instead will identify the areas of Jewish life that were depicted in the pages of interwar Polish-Jewish newspapers. This will reveal the extent to which Polish was a language involved in the cultural practices of Jewish daily life during that period. In the book The Practice of Everyday Life, Michel de Certeau introduces the category of "ordinary language," defined as a social "common place" associated with routine practices of everyday life, such as reading, talking, cooking, or dwelling. ${ }^{33}$ The Polish-Jewish press makes it possible to examine the functioning of Polish in this very role of "ordinary language" present in various areas of Jewish life.

In his concept, de Certeau refers not only to the philosophy of language, but also to the socio-linguistic perspective. Connections between colloquial language and everyday life are also analyzed in sociological studies, in which language is ascribed the role of constituting the latter. The constructivists Peter L. Berger and Thomas Luckmann emphasize that "[t]he language used in everyday life continuously provides . . the necessary objectifications and posits the order." ${ }^{34}$ According to this approach, the process of the vernacularization of Polish should be regarded as an element shaping popular knowledge and social imagination, as well as an important factor in cognitive mapping.

\section{Jewish press in the Polish language: From the public sphere to the private space}

To understand changes in the status of the Polish language in the Jewish environment that took place from the mid-nineteenth century to the 1930s,

\footnotetext{
${ }^{32}$ Stefan Żółkiewski, Kultura, socjologia, semiotyka literacka: Studia (Warsaw, 1979).

${ }_{33}$ Michel de Certeau, The Practice of Everyday Life, trans. Steven Rendall (Berkeley, 1988).

${ }^{34}$ Peter L. Berger, Thomas Luckmann, The Social Construction of Reality: A Treatise in the Sociology of Knowledge (New York-London, 1966), 35.
} 
let us look at Jewish newspapers published in the nineteenth century and during the interwar period. In the most general terms, the Jewish press in Polish, which began to appear in the 1860s, was assigned ideological goals and functions, and belonged to institutions that shaped the modern public sphere, in which communication between members of the community took place. ${ }^{35} \mathrm{In}$ a recent selection of articles from Izraelita [The Israelite], a weekly published in Warsaw for almost half a century (1866-1915), which promoted the assimilationist (integrationist) project, the editors categorize the articles according to their subject matter: religion, language, history, antisemitism, Zionism, emigration, art and literature, Jewish communities, and current events. In their commentary, they point out that the periodical was dominated by "ideological debates" and articles devoted to "important social, cultural, and political issues." ${ }^{136}$ Its reports on Jewish life focussed on the functioning of kehillot. The column devoted to these issues is described as a kind of news bulletin and review concerning "daily activities of the numerous institutions of the kehilla and private individuals." ${ }^{37}$

The private sphere and everyday life found their way onto its pages in a rather peculiar and marginal form: through commercial advertisements and classified ads, which offer an insight into contemporary furnishings, clothing style, hygiene, entertainment, leisure activities, and health care practices. ${ }^{38}$ Another type of reference to everyday life were descriptions of Jewish holiday customs. ${ }^{39}$

A similar profile was adopted by the weekly Jedność [Unity] published in Lwów at the beginning of the twentieth century (1907-1912). This periodical was also dominated by ideological commentaries and political debates. In fact, Jedność collaborated with Izraelita and frequently reprinted articles from the latter. Distinctly different, on the other hand, was the news chronicle in Jedność, which covered the activities of Jewish

${ }^{35}$ According to Jürgen Habermas, the press is a primary tool of communication in the public sphere. Krzysztof Jaskułowski, "Koncepcja sfery publicznej Jürgena Habermasa," Spotkania Europejskie 3 (2010), 74. See also Charles Taylor, Modern Social Imaginaries (Durham-London, 2004).

${ }^{36}$ Agnieszka Jagodzińska, "Ogłoszenia i reklamy," in Agnieszka Jagodzińska, Marcin Wodziński (eds.), "Izraelita” 1866-1915: Wybór źródet (Kraków-Budapest, 2015), 481; Zuzanna Kołodziejska, "Bieżące zdarzenia," in Jagodzińska, Wodziński (eds.), "Izraelita" 1866-1915, 457.

${ }^{37}$ Marcin Wodziński, "Sprawy gminne," in Jagodzińska, Wodziński (eds.), "Izraelita" 1866-1915, 439.

38 Jagodzińska, "Ogłoszenia i reklamy," 486.

39 Zuzanna Kołodziejska, "Izraelita” (1866-1915): Znaczenie kulturowe i literackie czasopisma (Kraków, 2014), 157-158. 
educational and charitable institutions, as well as the events organized by Jewish academic societies or political parties and organizations. The local column of Jedność records the flourishing Jewish cultural life at that time: dozens of public lectures on social, academic and literary subjects, dozens of election meetings and political rallies, dozens of musical concerts and theater performances organized throughout Galicia by the integrationist Bernard Goldman People's School Society, the Zionist Toynbee Halls, or the Organization of Independent Jews. ${ }^{40}$

Let us compare Izraelita and Jedność with the weekly Opinia / Nasza Opinia [Opinion / Our Opinion] published in 1933-1939, initially in Warsaw and later in Lwów. ${ }^{41}$ This weekly belonged to a rapidly growing wave of Jewish newspapers that espoused Jewish national orientation. Opinia, which defined its focus as politics, social issues, and literature, ardently declared its pro-Zionist stance. However, in addition to political and social commentaries, information on current domestic events and a Palestinian chronicle, the "Literatura - sztuka - nauka" [Literature, Art and Science] section, information on theater plays, new films, and radio broadcasts, it published supplements for women (“Życie Kobiety" [Woman's Life]), schoolchildren ("Świat Młodych" [World of the Youth]), and university students ("Opinia Akademicka" [Academic Opinion]). It also printed display advertisements and short ads.

Opinia shares the scope of its political, social and cultural interests, and partly its target audience, with the interwar Polish-Jewish dailies ${ }^{42}$ that formed one of the most characteristic phenomena of Jewish culture in the interwar period. For instance, in the 1930s, Nowy Dziennik [New Daily], published in Kraków from 1918 to $1939,{ }^{43}$ in addition to the latest news, local news, and extensive political and social commentaries, included medical

${ }^{40}$ Eugenia Prokop-Janiec, "Integrationalists in Galicia on the Eve of the First World War: The Weekly 'Jedność" (unpublished article).

${ }^{41}$ On a characterization of the weekly, see Monika Szabłowska-Zaremba, "'Opinia' 'Nasza Opinia': Tygodnik (Żydowski) Polityczno-Społeczny i Literacki (1933-1939)," in Agnieszka Karczewska, Sławomir J. Żurek (eds.), Prasa Żydów polskich: Od przeszłości do teraźniejszości (Lublin, 2016), 95-211.

42 Michael Steinlauf, “The Polish-Jewish Daily Press,” Polin 2 (1987), 219-245; Katrin Steffen, Jüdische Polonität: Ethnizität und Nation im Spiegel der polnischsprachigen jüdischen Presse 1918-1939 (Göttingen, 2004); ead., “'Polska - to także my!': Prasa polsko-żydowska 1918-1939," in Joanna Nalewajko-Kulikov (ed.), Studia z dziejów trójjęzycznej prasy żydowskiej na ziemiach polskich (XIX-XX w.) (Warsaw, 2012), 129-146.

${ }^{43}$ On Nowy Dziennik see: Czesław Brzoza, "Pierwsze lata 'Nowego Dziennika,' organu syjonistów krakowskich," Rocznik Historii Prasy Polskiej 1 (1998), 1-2:23-47; id., "The Jewish Press in Kraków (1918-1939)," Polin 7 (1992), 139-140. 
advice, recipes, tips for housewives, a women's fashion section, a bridge and chess column, a humor and puzzle column, sports news, theater and cinema listings, radio schedules, information about forthcoming concerts, exhibitions and lectures, engagement and wedding announcements, and obituaries. It published also supplements: "Lekarz Domowy" [Family Doctor] (1926-1939), "Literatura i Sztuka" [Art and Literature] (later "Literatura, Sztuka i Nauka") (1926-1939), "Głos Kobiety Żydowskiej” [Voice of the Jewish Woman] (1928-1939), "Życie Akademickie" [Academic Life] (1931-1937), "Informator Palestyński” [Palestinian Chronicle] (1935-1937), and, for children, "Dzienniczek" [Little Diary] (1928-1939) and "Dom i Szkoła" [Home and School] (1929-1932), as well as displayed advertisements and small ads. It should be added that Nowy Dziennik was launched as a paper devoted to news and political topics, so it was initially dominated by reports on current events and commentaries on social and political issues. Sections and supplements introducing other topics, such as household management, family affairs, and leisure activities, were added gradually in subsequent years. The classified ads section, which could be seen as a chronicle of everyday life, was also steadily enlarged. Advertisements of vacancies, sale and purchase, various services, educational institutions, matrimonials and obituaries provide an insight into the habits, material world, and mentality of the readers. ${ }^{44}$ It is those classified ads that are of particular interest in studying the process of the vernacularization of Polish. In the 1930s, they are increasingly used not merely for making business offers, such as purchase, sale, rent, or service, but also for communication in personal affairs. It is through their agency that the readers of Polish-Jewish newspapers search for life partners, announce engagements, and express sorrow for the departed.

As editors of Yiddish press observed in the early 1930s, Jewish dailies in the Polish language became a substantial part of the press market and were in competition with Yiddish dailies for classified advertisements. Moment's editor Noah Pryłucki acknowledged in his recollections that growing linguistic Polonization resulted in the fact that the young generation did not read in Yiddish but in Polish. That is why for the prospect reader of Jewish press instead of subscribing to Yiddish newspapers it was much more practical to subscribe to Polish-Jewish Nasz Przeglad [Our Review] that could be read by him, his wife, and his children. Personal columns

${ }^{44}$ For more on advertisements in the Polish-Jewish press, see Steffen, "'Polska - to także my!'," 139-140. 
and obituary sections enlarged in Polish-Jewish press and diminished in Yiddish dailies. ${ }^{45}$

The introduction by Polish-Jewish dailies of columns and supplements addressed to different groups was a sign of increasing diversification among readers of the Polish-Jewish press. Another institutional response to this process was the emergence of periodicals with a more narrowly defined target audience, such as Ewa (1928-1933), a women's weekly launched in the late 1920s. The ideological profile of this weekly has been described as a combination of Zionism and feminism. ${ }^{46}$ Women's problems were discussed on its pages not only in social commentaries on their role, status, and rights, but also in special columns dedicated to health, beauty care, fashion, and household management.

The bibliography Żydowskie periodyki i druki okazjonalne w języku polskim [Jewish Periodicals and Occasional Publications in Polish] by Alina $\mathrm{Cała}^{47}$ demonstrates the importance of periodicals for children and youth, especially school newspapers, within the Polish-Jewish press in the interwar period. ${ }^{48}$ The latter were published mainly by students of gymnasiums and vocational schools (e.g. nursing schools) writing about various problems of school and teenage life.

\section{Popular press in the 1930 s}

Another example of the vernacularization of Polish in the 1930s is the Warsaw daily 5-ta Rano [Five in the Morning], published from 1931 till 1939. ${ }^{49}$ It was a sensationalist newspaper, and its appearance at the beginning of the 1930s signaled diversifying social circuits of Jewish culture in Polish and the emergence of new audiences using the Polish language. It

45 Cwi Pryłucki, Wspomnienia (1905-1939), trans. Agata Kondrat, ed. Joanna Nalewajko-Kulikov (Warsaw, 2015), 140. In the late 1930s, to gain new readers, editors of Yiddish dailies launched Polish-Jewish dailies. See ibid., 156.

${ }^{46}$ Eva Plach, "Feminism and Nationalism on the Pages of 'Ewa. Tygodnik' 1928-1933," Polin 18 (2005), 241-262; Maria Antosik-Piela, "Feminizm po żydowsku: Tygodnik 'Ewa' (1929-1939)," Midrasz (2008), 12:44-48.

${ }^{47}$ Alina Cała, Żydowskie periodyki i druki okazjonalne $w$ języku polskim: Bibliografia (Warsaw, 2005).

${ }^{48}$ For more about this type of periodicals, see Jerzy Jarowiecki, "Prasa dla dzieci i młodzieży oraz prasa młodzieżowa w latach 1918-1939," in Mieczysław Adamczyk, Jerzy Jarowiecki (eds.), Prasa dziecięca i mtodzieżowa: Studia i materiały (Kielce, 1982), 29-35.

${ }^{49}$ For more about 5-ta Rano, see Eugenia Prokop-Janiec, "Warszawa: '5-ta Rano.' Sensacja i nowoczesność," in ead., Pogranicze polsko-żydowskie: Topografie i teksty (Kraków, 2013). 
is worth noting that the 1930s saw the development of mass readership in many other European countries. ${ }^{50}$ Sociologists of culture emphasize the importance of the increasingly widespread access to primary education in the 1920s, which prepared the ground for the popularization of reading in the following decade, when "the alumni of Polish primary schools of 1918-1930 entered their adult lives." 51 This process was also reflected in the appearance of a new group of Polish-Jewish readers. Dismissed by many historians as an embarrassing manifestation of the triumph of vulgar entertainment pandering to the tastes of culturally uncouth common people, ${ }^{52}$ 5-ta Rano had the position of one of the market leaders among interwar Polish-Jewish newspapers. The daily published regular supplements for women, schoolchildren, university students, sport fans, film aficionados, and literature lovers, which could be regarded as an indication of the social and generational traits of Jewish audiences that were sufficiently familiar with the Polish language to join the ranks of popular-press readers.

According to Jostein Gripsrud,

The style and content of the popular press ... could be described as being marked by sensationalism and personalization. This means that the papers in question have a special preference for material that is shocking in some way, and material that concerns individuals as private persons..$^{53}$

In 5-ta Rano this preoccupation with scandals and the private sphere, as well as with family life and the functioning of local communities, was reflected in all kinds of publications, such as faits divers, local news, court reports, letters from the readers, and advice from the editors.

It is especially the letter section that seems indicative of the vernacularization of the Polish language. Letters belong to the literature of personal document. ${ }^{54}$ The editors of 5-ta Rano appreciated the intimate nature of correspondence, publishing texts that dealt with relationships between family members, friends, fiancés, paramours. The column titled " $Z$ serca do serca" [From Heart to Heart] (and subtitled "Intymne rozmowy

${ }^{50}$ Stefan Żółkiewski, Kultura literacka (1918-1932) (Wrocław, 1973), 281.

${ }^{51}$ Ibid., 265.

${ }^{52}$ Marian Fuks, Prasa żydowska w Warszawie 1823-1939 (Warsaw, 1979), 275; Wiesław Władyka, Krew na pierwszej stronie: Sensacyjne dzienniki Drugiej Rzeczypospolitej (Warsaw, 1982), 25.

53 Jostein Gripsrud, "The Aesthetics and Politics of Melodrama," in Peter Dahlgren, Colin Sparks (eds.), Journalism and Popular Culture (London, 1992), 85.

${ }^{54}$ For more on the special role of letters to the editors, see Małgorzata Szpakowska, Chcieć i mieć: Samowiedza obyczajowa w Polsce czasu przemian (Warsaw, 2003), 126-131. 
z czytelnikami: Odpowiedzi na piśmienne zapytania" [Intimate Talks with the Readers: Answers to Written Questions]), which contained letters from the readers answered by the column editor, was advertised as "a column on life and a school of life ... a laboratory of intimate matters, as well as an educational experience." ${ }^{55}$ Calling the letters "a kaleidoscope of our [Jewish] existence," ${ }^{56}$ the editors stressed that they regarded them as a form of social document. Their authors included girls from Warsaw and also "maidens from religious families" in the provinces, ${ }^{57}$ young women-often mothers and wives-from large cities and from shtetlekh; some letters were also written by teenage schoolboys, young men, and heads of families. They asked for advice on all kinds of matters related to sex, marriage, family, health, work, education, emigration, or etiquette. It should be added that similar reader's letter columns—under similar titles—could also be found in interwar sensationalist dailies published in Yiddish. ${ }^{58}$

Like other mass circulation newspapers, 5-ta Rano devoted particular attention to sensational and scandalous news, and frequently broke social taboos, for example, those related to sexuality. Series of articles such as "Tajemnice małżeńskie" [Marital Secrets], "Tajemnice gabinetu lekarskiego" [Secrets of Doctor's Surgery], or "Tajemnice prostytucji” [Secrets of Prostitution] habitually shocked the reader with stories of transgression-incest, rape, prostitution. On the other hand, it must be emphasized that the paper presented extremely modern and open attitudes, publishing articles on birth control, discussing the question of abortion, or informing about the controversial books by the sexologist Magnus Hirschfeld and the sexual reformer Benjamin Lindsey. It also commented on the results of studies of sexual awareness among youth and advertised booklets and guides: "Sexual life! Sexuality! For adults only. 10 valuable and useful books." 59

John Fiske argues that popular news show "ordinary people experiencing the breakdown of social norms, or living beyond the limits of

55 St. Omnibus, "Z serca do serca: Intymne rozmowy z czytelnikami," 5-ta Rano 4 (1934), 139.

${ }^{56}$ Incognito, "Z serca do serca: Intymne rozmowy z czytelnikami - odpowiedzi na piśmienne zapytania," 5-ta Rano 1 (1931), 4.

57 "Z serca do serca," 5-ta Rano 1 (1931), 88.

${ }^{58}$ Nathan Cohen, “'Shund' and the Tabloids: Jewish Popular Reading in Inter-War Poland," Polin 16 (2003), 194.

59 5-ta Rano 2 (1932), 180. 
the explanatory power of official knowledge." ${ }^{60}$ The emphasis on the unusual, astonishing, and shocking manifested itself in reports not only on scandals, but also on new phenomena that offended traditional moral sensibilities. 5-ta Rano very often reported on surprising fusions of tradition and new models of behavior. The column "Tajemnice małżeńskie" related, for example, the story of a married couple who traveled the road "from a skiing season in Krynica to a divorce in the rabbinate of Warsaw"61 and described an unsuccessful first meeting (called onkuk in Yiddish) of a prospective bride, an emancipated Jewish girl, a swimming champion, and her potential bridegroom, an Orthodox young man recommended by a shadchan. The daily also wrote about conflicts caused by differences between religious and secularized lifestyles, such as a litigation between a pious but hot-blooded inhabitant of Targowa Street in Warsaw and his godless neighbor who broke the Shabbat by smoking cigarettes. ${ }^{62}$

This combination of analysis and criticism of social norms with descriptions of tradition and its transformations is well illustrated by the attitude of the newspaper to the custom which made the family of the bride pay a dowry. The daily devoted a great deal of attention to this problem:

In every family with grown-up daughters, quiet, but tremendous, dowry tragedies take place. One does not talk openly about it, no one even mentions it, but it is one of the gravest social afflictions, which should be more frequently discussed in public. One should try to do something about this horrible superstition by moulding public opinion. ${ }^{63}$

The daily condemned the "dowry mania" as a "demoralizing" factor, and reported, in the crime and gossip columns, on the plague of dowry fraud, on family conflicts, and on trials of swindle cases.

It is worth noting that the newspaper raised feminist issues on many occasions. In 1932, 5-ta Rano published a series of articles discussing whether a woman could work outside home while at the same time being a wife and mother. ${ }^{64}$ In the years 1934-1935, on the other hand, the daily initiated a debate on the liberated woman as a new social type and

${ }^{60}$ John Fiske, "Popularity and the Politics of Information," in Dahlgren, Sparks (eds.), Journalism and Popular Culture, 58.

${ }_{61}$ "Tajemnice małżeńskie: Od sezonu narciarskiego w Krynicy do rozwodu w rabinacie warszawskim," 5-ta Rano 1 (1931), 1.

${ }_{62}$ "Na ławie oskarżonych," 5-ta Rano 1 (1931), 6.

${ }^{63}$ Incognito, "Z serca do serca," 5-ta Rano 2 (1932), 258.

${ }^{64}$ "Czy kobieta może być koleżanką zawodową a zarazem żoną i matką?", 5-ta Rano 2 (1932), 152. 
phenomenon. In this debate, the journalists, among others, defended the right of women to work and wondered why it was believed that "an unemployed man is more deserving of sympathy than an unemployed woman." ${ }^{65}$

Symptomatic signs of changing social norms can be detected in advice on etiquette. For instance, in 1934, when offering advice on proper dress and behavior at a five o'clock party or an evening dance, the newspaper praised dancing as a democratic form of entertainment, more socially accessible and not overly constrained by rules of propriety. ${ }^{66}$

\section{Popular literature: Serialized novels}

The most important genre of popular literature published by the Jewish press were serialized novels. ${ }^{67}$ Printed in the columns of 5-ta Rano novels "derived from Jewish life" 68 offered a wide range of observation of manners-spanning the everyday and the unusual, the traditional and the modern. This quasi-genre qualification was also applied to novels published at the same time in the Yiddish press, and its function, according to Chone Shmeruk, was to signal that the novel was set in "an environment well familiar to the Jewish reader." ${ }^{99}$ What is more, the authenticity of portrayed manners and social realities was regarded as an important quality capable of attracting the public. According to the editors, the reader had the right to expect that a serialized novel "would come from the pen of a good writer and would derive from real life," $" 70$ and that he

${ }^{65}$ Luba Waffel, "Mężczyźni zmieńcie taktykę: Artykuł dyskusyjny na temat kobiety wyzwolonej," 5-ta Rano 4 (1934), 350.

66 "Na sali dancingowej," 5-ta Rano 4 (1934), 56.

${ }^{67}$ On the role of serialized novels in the growth of readership of the Yiddish press, see: Joanna Nalewajko-Kulikov, Mówić we własnym imieniu: Prasa jidyszowa a tworzenie żydowskiej tożsamości narodowej (do 1918 roku) (Warsaw, 2016), 122-125.

${ }^{68}$ For more on this type of novel, see Eugenia Prokop-Janiec, "Międzywojenna polskożydowska powieść w odcinkach," in ead., Pogranicze polsko-żydowskie, 169-199.

${ }^{69}$ Chone Shmeruk, "Responses to Antisemitism in Poland, 1912-36: A Case Study of the Novels of Michal Bursztyn," in Jehuda Reinharz (ed.), Living with Antisemitism: Modern Jewish Responses (Hanover-London, 1987). Adam Kopciowski notes that novels with the same quasi-genre qualification were also published in the Lublin daily Lubliner Tugblat. See Adam Kopciowski, Wos hert zich in der prowinc?: Prasa żydowska na Lubelszczyźnie i jej największy dziennik "Lubliner Tugblat" (Lublin, 2015), 464.

70 "Komentarz redakcji," 5-ta Rano 2 (1932), 286. 
would be able to recognize among the characters "many a familiar figure: a neighbor, acquaintance, friend, or even relative."71

Many works printed in 5-ta Rano belonged to the genre of journalistic novel, based on the events that had shocked public opinion. Introducing publications of this kind, the editors insisted that they were faithful in retellings of facts and advertised them as a kind of pitaval. For example, some "contemporary novels about the life of Warsaw" were advertised as fictionalizations of actual events: a narrative "derived from the life of assimilated Jews, a brilliant retelling of the story of a certain Jewish family in Warsaw"72 or "the story of a well-known Jewish family from Warsaw who, until recently, occupied a leading place among the wealthiest circles of the capital." 73 In addition, the relevance and the documentary effect of these novels were often achieved by matching their themes with debates concurrently taking place in the newspaper-for example, debates on the economic crisis, migration to Palestine, social roles of women, or abortion.

One of the fundamental rules of the serialized interwar novels, both Polish and Yiddish, was that their plot had to be set in places known to the reader. ${ }^{74}$ The action of novels published in 5-ta Rano often took place in Warsaw and its vicinity (e.g. Otwock), from where it sometimes moved briefly to other Polish cities: Kraków, Łódź, Poznań, or Lublin. Such episodes usually contained elements of the Jewish local color, for example a description of the Lublin Yeshiva and yeshiva bokhers who studied there or scenes from the Jewish quarter in Kraków which emphasized its Orthodox character.

In the Polish-Jewish novels set in Warsaw, the center of the city map was the "northern quarter":

It was Warsaw in the summer. Poor families of craftsmen, inhabiting shops next to their workrooms in the narrow streets of the Jewish quarter, lived nearly outdoors. The streets were teeming with people and crowded, the shouting and hubbub of street peddlers mixed with the din of various workshops. All this together created a cacophony characteristic of the populous, bustling Jewish street. ${ }^{75}$

71 An advertisement of the novel Podrzutek, 5-ta Rano 5 (1935), 38.

72 An advertisement of Kobieta bez twarzy, 5-ta Rano 5 (1935), 272.

73 An advertisement of Ojciec czy kochanek, 5-ta Rano 4 (1934), 87.

${ }^{74}$ Umberto Eco, Superman w literaturze masowej. Powieść popularna: między retoryka a ideologia, trans. Joanna Ugniewska (Kraków, 2008).

75 Jerzy Walder, "Podrzutek," 5-ta Rano 5 (1935), 206. 
The space is usually portrayed from the perspective of characters moving through, and the narrative re-creates the scenery of daily life by using the actual names of streets, squares or cafés (e.g. Nalewki, Gęsia, Dzika, Krochmalna, plac Grzybowski, Semadeni Café).

On the other hand, a large portion of serialized novels drew on the convention of melodrama, the genre enjoying enormous success in popular art. Such novels appeared in 5-ta Rano in its two main varieties: the social and historical ones, in which the fictional structures of melodrama were combined with analyzes of social phenomena or descriptions of historical events. John Cawelti regards melodrama as a genre that confirms the "conventional moral or philosophical principle as the inherent basis of cosmic order." " Melodrama collides the everyday with the unusual, but the melodramatic imagination transforms chaos into order and ensures the ultimate triumph of justice: the victory of good over evil, the reward of the righteous and the punishment to the wicked.

To put it in a nutshell, the formulas of the sensationalist daily newspaper and lowbrow literary genres were particularly suitable for focussing on issues related to social mores, the private sphere and everyday life.

\section{Conclusion}

The Jewish press in Polish was one of the key institutions in which the Polish language served as a means of written communication in Jewish life. What is important, it was also linked with other cultural institutions that supported and extended the contact of the Jews with the Polish language, such as theater, radio, and cinema. The interwar dailies published not only cinema and theater listings, but also schedules of radio programs, theater reviews, and information about forthcoming films and radio talks.

The press can be regarded as one of the main sources indicating key modern areas of Jewish communication in Polish and documenting the expansion of this communication from the public to the private sphere, from the exchange of opinions on social, political, and artistic problems to the discussion of everyday issues, family life, or even the most intimate subjects.

The important landmarks in this process were the appearance of the daily press after 1918 and then the advent of the mass circulation press

${ }^{76}$ John G. Cawelti, Adventure, Mystery, and Romance: Formula Stories as Art and Popular Culture (Chicago, 1976), 262. 
addressed to the mass audience in the 1930s. The development of a popular circulation of the Jewish press in Polish testifies to the growing numbers of Jews who used Polish as a Jewish vernacular language. It disestablished the existing model of the relationship between the Jewish daily press in Polish and the press in Yiddish, which was based on differences in their subject matter. In that model, according to Joanna Nalewajko-Kulikov, the choice of the language "determined the content and ways in which it was expressed."77 The new situation was signaled not only by the fact that the daily Polish and Yiddish newspapers were issued by the same publishers, but above all, by the circulation of editors, journalists, writers, and texts between them. ${ }^{78}$

Anthropologists emphasize the importance of various social "situations of speaking about everyday life" for both scholarly and popular reflection on this aspect of our existence. ${ }^{79}$ The Polish-Jewish popular daily press offered such an opportunity through journalistic and literary genres dealing with topics from everyday life. Thus, it formed one of the platforms for communication in the Polish language on topics related to family, marriage, sex, health, fashion, cooking, housekeeping, raising children, schools and universities, sport, entertainment, or etiquette. While publishing special issues for Jewish holidays, the Polish-language dailies included in them not only religious commentaries and historical or literary materials, as the nineteenth-century press did, but also recipes for traditional dishes and reports (including those sent in by the readers) describing the private and intimate dimension of holidays celebrated by Jewish families.

We may therefore suppose that just before the Holocaust the Polish language was on the best way to achieve among the Jews the status of "ordinary language" associated with the cultural practices of "creating everyday life."

Translated from the Polish by Grzegorz Dąbkowski

\footnotetext{
77 Joanna Nalewajko-Kulikov, "Prasa żydowska na ziemiach polskich," in ead. (ed.), Studia z dziejów trójjęzycznej prasy żydowskiej, 9.

${ }^{78}$ An example of this circulation is the presence of some authors, such as Urke Nachalnik and Róża Jakubowicz, in the Polish-Jewish and Yiddish popular press.

${ }^{79}$ Roch Sulima, "Moda na codzienność: Kategoria 'codzienności' w kulturze ponowoczesnej,” Kultura Wspótczesna 19 (2011), 4:182.
} 


\section{Bibliography}

\section{Primary sources}

5-ta Rano 1931-1939.

Jagodzińska, Agnieszka, Wodziński, Marcin (eds.), "Izraelita” 1866-1915: Wybór źródet (Kraków-Budapest, 2015).

Pryłucki, Cwi, Wspomnienia (1905-1939), trans. Agata Kondrat, ed. Joanna Nalewajko-Kulikov (Warsaw, 2015).

\section{Secondary sources}

Adamczuk, Lucjan, Łodziński, Sławomir, "Wprowadzenie," in eid. (eds.), Mniejszości narodowe w Polsce w świetle Narodowego Spisu Powszechnego z 2002 roku (Warsaw, 2006).

Anderson, Benedict, Imagined Communities: Reflections on the Origin and Spread of Nationalism (New York, 2006).

Antosik-Piela, Maria, "Feminizm po żydowsku: Tygodnik 'Ewa' (1929-1939)," Midrasz (2008), 12.

Bednarczuk, Monika, “Wielojęzyczność w kontekście akademickim: Sieci naukowe, samodoskonalenie i polityka w Wilnie (w końcu XVIII i pierwszych dekadach XIX wieku)," Wielogłos 10 (2016), 2.

Berger, Peter L., Luckmann, Thomas, The Social Construction of Reality: A Treatise in the Sociology of Knowledge (New York-London, 1966).

Brzoza, Czesław, "The Jewish Press in Kraków (1918-1939)," Polin 7 (1992).

Brzoza, Czesław, "Pierwsze lata 'Nowego Dziennika,' organu syjonistów krakowskich," Rocznik Historii Prasy Polskiej 1 (1998), 1-2.

Cała, Alina, Żydowskie periodyki i druki okazjonalne w języku polskim: Bibliografia (Warsaw, 2005).

Cawelti, John G., Adventure, Mystery, and Romance: Formula Stories as Art and Popular Culture (Chicago, 1976).

Certeau, Michel de, The Practice of Everyday Life, trans. Steven Rendall (Berkeley, 1988).

Cohen, Nathan, "Czytelnictwo książek polskich w żydowskich bibliotekach w okresie międzywojennym," in Eugenia Prokop-Janiec, Sławomir J. Żurek (eds.), Literatura polsko-żydowska: Studia i szkice (Kraków, 2011).

Cohen, Nathan, "'Shund' and the Tabloids: Jewish Popular Reading in Inter-War Poland," Polin 16 (2003).

Cohen, Nathan, “Zapominanie języka: Polszczyzna i jidysz wśród młodzieży żydowskiej w międzywojennej Polsce," trans. Izabela Suchojad, in Eugenia Prokop-Janiec, Marek Tuszewicki (eds.), Polskie tematy $i$ konteksty literatury żydowskiej (Kraków, 2014).

Dahlgren, Peter, Sparks, Colin (eds.), Journalism and Popular Culture (London, 1992). 
Eco, Umberto, Superman w literaturze masowej. Powieść popularna: między retoryka a ideologia, trans. Joanna Ugniewska (Kraków, 2008).

Fuks, Marian, Prasa żydowska $w$ Warszawie 1823-1939 (Warsaw, 1979).

Harshav, Benjamin, The Polyphony of Jewish Culture (Stanford, 2007).

Jagodzińska, Agnieszka, Pomiędzy: Akulturacja Żydów Warszawy w drugiej połowie XIX wieku (Wrocław, 2008).

Karczewska, Agnieszka, Żurek, Sławomir J. (eds.), Prasa Żydów polskich: Od przeszłości do teraźniejszości (Lublin, 2016).

Kołodziejska, Zuzanna, "Izraelita” (1866-1915): Znaczenie kulturowe i literackie czasopisma (Kraków, 2014).

Kopciowski, Adam, Wos hert zich in der prowinc?: Prasa żydowska na Lubelszczyźnie i jej największy dziennik "Lubliner Tugblat" (Lublin, 2015).

Löw, Chaim, Smok w słowiczym gnieździe: Żydzi w poezji Odrodzonej Polski (Warsaw, 1934).

Majewska, Justyna, “‘Czym wytłumaczy Pan...?’ Inteligencja żydowska o polonizacji i asymilacji w getcie warszawskim,” Zagłada Żydów 11 (2015).

Nalewajko-Kulikov, Joanna, Mówić we własnym imieniu: Prasa jidyszowa a tworzenie żydowskiej tożsamości narodowej (do 1918 roku) (Warsaw, 2016).

Nalewajko-Kulikov, Joanna (ed.), Studia z dziejów trójjęzycznej prasy żydowskiej na ziemiach polskich (XIX-XX w.) (Warsaw, 2012).

Plach, Eva, "Feminism and Nationalism on the Pages of 'Ewa. Tygodnik' 19281933," Polin 18 (2005).

Prokop-Janiec, Eugenia, Pogranicze polsko-żydowskie: Topografie i teksty (Kraków, 2013).

Ringelblum, Emanuel, Kronika getta warszawskiego: Wrzesień 1939 - styczeń 1943, trans. Adam Rutkowski (Warsaw, 1988).

Sagan-Bielawa, Mirosława, "Pytanie o język w spisach ludności na ziemiach polskich (lata 1789-2011)," in Władysław T. Miodunka, Anna Seretny (eds.), Język, literatura i kultura polska w świecie (Kraków, 2016).

Shandler, Jeffrey, Adventures in Yiddishland: Postvernacular Language and Culture (Berkeley, 2006).

Shmeruk, Chone, "Hebrew-Yiddish-Polish: A Trilingual Jewish Culture," in Yisrael Gutman, Ezra Mendelsohn, Jehuda Reinharz, Chone Shmeruk (eds.), The Jews of Poland between Two World Wars (Hanover-London, 1989).

Shmeruk, Chone, "Responses to Antisemitism in Poland, 1912-36: A Case Study of the Novels of Michal Bursztyn," in Jehuda Reinharz (ed.), Living with Antisemitism: Modern Jewish Responses (Hanover-London, 1987).

Steffen, Katrin, Jüdische Polonität: Ethnizität und Nation im Spiegel der polnischsprachigen jüdischen Presse 1918-1939 (Göttingen, 2004).

Steffen, Katrin, “'Polska - to także my!': Prasa polsko-żydowska 1918-1939,” in Joanna Nalewajko-Kulikov (ed.), Studia z dziejów trójjęzycznej prasy żydowskiej na ziemiach polskich (XIX-XX w.) (Warsaw, 2012).

Steinlauf, Michael, "The Polish-Jewish Daily Press," Polin 2 (1987).

Stopnicka Heller, Celia, On the Edge of Destruction: Jews of Poland between the Two World Wars (New York, 1980). 
Strzelecki, Zbigniew, Toczyński, Tadeusz, Latuch, Kazimierz (eds.), Spisy ludności w Rzeczypospolitej Polskiej 1921-2002: Wybór pism demografów (Warsaw, 2002). Szabłowska-Zaremba, Monika, “'Opinia’ - 'Nasza Opinia’: Tygodnik (Żydowski) Polityczno-Społeczny i Literacki (1933-1939),” in: Agnieszka Karczewska, Sławomir J. Żurek (eds.), Prasa Żydów polskich: Od przeszłości do teraźniejszości (Lublin, 2016).

Szpakowska, Małgorzata, Chcieć i mieć: Samowiedza obyczajowa w Polsce czasu przemian (Warsaw, 2003).

Taylor, Charles, Modern Social Imaginaries (Durham-London, 2004).

Veidlinger, Jeffrey, Jewish Public Culture in the Late Russian Empire (Bloomington, 2009).

Władyka, Wiesław, Krew na pierwszej stronie: Sensacyjne dzienniki Drugiej Rzeczypospolitej (Warsaw, 1982).

Żółkiewski, Stefan, Kultura literacka (1918-1932) (Wrocław, 1973).

Żółkiewski, Stefan, Kultura, socjologia, semiotyka literacka: Studia (Warsaw, 1979).

Eugenia Prokop-Janiec Jagiellonian University, Cracow eugenia.prokop-janiec@uj.edu.pl 